\title{
İNSAN HAKLARI EĞİTIMI: KARŞILAŞTIRMALI BİR DEĞERLENDİRME
}

\author{
Ayla OKTAY* \\ Özgül Polat UNUTKAN ${ }^{* *}$
}

$\ddot{O ̈ z e t:}$

Geleceğin çağdaş insanının yetiştirilmesinde demokrasi eğitimi son derece önemlidir. Demokrasi eğitiminin temeli de insan haklart eğitiminden geçmektedir. Her ülkede insan haklartyla iliş̧kili eğitim uygulamaları farklıllk göstermektedir. Bu durum küresel değerlerin ülke vatandaşlart tarafindan benimsenmesini güçleştirmektedir. Insan haklarının bireyler tarafindan benimsenmesi hedeflense de diğer ülkelerle yürütülen ortak çalışmaların sinırlı oluşu, ortak bakış açısının da gelişmesini engellemektedir. Ayrıca "insan hakları evrensel düşücesi" nin her ülke tarafindan farklı biçimlerde özümsenmesi, insanlar arasında küreselleşmenin getirdiği bütüncül bakış açısının geliştirilmesini sağlayamadı̆ı gibi, eşitsizliklere de neden olmaktadır. Farkll ülkelerde yaptlan insan haklarl eğitimine ilişkin uygulamalarin ortaya konmast, temelde Insan Haklarl Evrensel Bildirgesi'nin esasına uygun olarak uygulanmasını kolaylaştıracaktır. Makalede, Türkiye'deki insan hakları eğitiminin tarihsel gelişimi ve çeşitli ülkelerde insan hakları eğitimi için yapılan uygulamalar ele alınmıştır. Çalışma, farklı insan hakları eğitimi uygulamalarının incelenmesi, ülkemizin insan haklarl eğitimin neresinde olduğunu göstermesi, çeşitli ülkelerde insan hakları eğitimiyle ilgili yapılan uygulamaların, benzer ve farklı yönlerini ortaya koyması açısından oldukça önemlidir.

Anahtar Kelimeler: Insan Haklarl Eğitimi, Avrupa Insan Haklarl Sözleşmesi, Avrupa Konseyi

\section{Abstract:}

Democracy has a crucial role in the education process of future generations and human rights education constitutes one of the main elements of democracy education. The education programs on human rights

\footnotetext{
*Prof. Dr., Marmara Üniversitesi Atatürk Eğitim Fakültesi Öğretim Üyesi

** Dr., Marmara Üniversitesi Atatürk Eğitim Fakültesi İlköğretim Bölümü Okul Öncesi Eğitimi A.B.D. Öğretim Görevlisi
} 
depicts differences among countries. As a result of this, the global human rights values are hardly accepted by the citizens of different countries. Despite the main target of human rights education concentrates on individuals, limited common activities in this area decreases the possibility of a common approach. Moreover, the differences in internalisation of universal thought on human rights not only negatively affect the unique view provided by globalisation, but also cause inequity. Examining various applications of human rights education will also be helpful for the proper implementation of Universal Declaration of Human Rights. In this paper, the historical evolution of human rights education in Turkey is examined as well as different other human rights education applications in other countries. This paper, therefore, provides a comparative analysis of human rights education and evalutes Turkey's situation in the light of human right education.

Keywords: Human rights education, European Convention on Human Rights, Council of Europe

\section{Giriş}

Eğitim en genel anlamda, bireylerde davranış, duyuş ve düşünüş değişikliği meydana getirme amacını gerçekleştirme sürecidir. Eğitimin demokrasilerin yaşaması için gerekli bir şart olduğu düşünüldüğünde, demokrasinin vazgeçilemez öğesi olan insan hakları önem kazanmaktadır. Çünkü bir siyasal rejim olarak demokrasi, insan haklarının gerçekleştirildiği düzeni temsil eder (Çeçen, 2000). Böylece demokratik rejimlerde insan hakları eğitimi hem ayrı bir alan olarak hem de sosyal bilimlerle ilintili pek çok dersin bir amacı olarak dikkat çekmektedir.

Demokratik devlet ilkesi, cumhuriyet kavramını tamamlayan, ona somut nitelik kazandıran ilkelerden birdir. Lâiklik ise demokrasinin ön koşuludur (Karakütük, 2001). İnsan hakları, hukuk devleti ve demokrasi birbirine sıkı biçimde bağlıdır. İnsan haklarına ve temel özgürlüklere saygı, demokrasinin temel özelliklerindendir. Eğitim, alanında, yurttaş için demokrasinin gerekliliğini kolaylaştıran her şey, insan haklarına saygıya ve bu saygının öğrenilmesine bağlıdır (TİHAK, 1998: 16). Dolayısıyla demokrasiyi içselleştirmiş vatandaşların yetişmesi insan hakları eğitimi yoluyla gerçekleştirilebilir. 
Insan Hakları evrensel bildirgesi tek bir belge olmasına rağmen, her ülkede insan haklarıyla ilişkili eğitim uygulamaları farklılık göstermektedir. Bu durum küresel değerlerin ülke vatandaşları tarafından benimsenmesini güçleştirmektedir. Ayrıca "insan hakları evrensel düşüncesi" nin her ülke tarafından farklı biçimlerde özümsenmesi, tüm insanların, insan hakları konusunda ortak değerler geliştirilmesini sağlayamadığı gibi, eşitsizliklere de neden olmaktadır. Bildirgenin esasını zedelemeyecek evrensel uygulamalar yapılması, "tüm insanlar arasında demokratik değerlere saygı" idealinin gerçekleşmesi açısından oldukça önemlidir. Bu nedenle farklı ülkelerde yapılan insan hakları eğitimine ilişkin uygulamaların ortaya konması gerekmektedir.

Bu çalışmada, ülkemizdeki insan hakları eğitiminin tarihsel gelişimi ve çeşitli ülkelerde insan hakları eğitimi için yapılan uygulamalar ele alınmıştır. Çalışma, farklı insan hakları eğitimi uygulamalarının incelenmesi, ülkemizin insan hakları eğitimin neresinde olduğunu göstermesi, çeşitli ülkelerde insan hakları eğitimiyle ilgili yapılan uygulamaların, benzer ve farklı yönlerini ortaya koymayı amaçlamaktadır.

\section{1. İlk Adımlar: İnsan Hakları Eğitiminin Uluslararası Gelişimi}

İnsan hakları temelde hiçbir sınıfın ya da kesimin ayrıcalığı olmadan yalnızca insan olmayla kazanılmış bazı hakları ifade etmektedir. İnsanlık onurunun gereği olarak sahip olunan bu haklar nitelik yönüyle dokunulmaz, vazgeçilmez ve kişiliğe bağlı haklardır (Yeşil, 2002: 25). Doğan'a (2002) göre insan hakları, insanın tek tek kişilerle ve iktidarla ilişkileri içinde kendi malı olarak elinde bulundurduğu, kurallarla yönetilen ayrıcalıklardır. Bu tanım ışığında insan hakları kavramının ana hatları şu şekilde sıralanabilir.

İnsan haklar1;

- Evrenseldir. Bütün insanların ve hatta dünyaya henüz gelmemiş çocukların sahip olması gereken haklardır.

- Özgürlükçüdür. İnsanın özgürce yaşama ve gelişmesinin temelidir.

- Eşitlikçidir. Doğuştan tüm insanlar bir ve eşittir.

- Barışçıdır. Barış, insanların yaşamaları için gereklidir. İnsan hakları barışın sağlanmasında etkili ve ısrarlıdır.

- Sorumluluk telkin edicidir. Sorumsuz davranışlar insan ve toplumların huzurunu bozar ve bunlara göre de modern demokrasilerde insan hakları 
yalnızca yasalarla belirlenmekle kalmayıp, bireylere haklarını yargı yoluyla koruma olanak ve güvencesini veren bir işlev ve görünüm kazanmıştır (Doğan, 2002: 237).

İnsan haklarının düşünsel temelleri çok eski dönemlere kadar dayanır. Ancak insan haklarının tarihi gelişimi içinde iki önemli nokta oldukça dikkat çekicidir. Bunlardan ilki 1789 Meclisi tarafından kabul edilen ve 1789 Fransız Devrimi ile birlikte, Fransız anayasalarının daima başlangıcını oluşturan "İnsan ve Yurttaş Hakları Bildirisi"dir. Bu bildiride, kişi hürriyetleri, sosyal eşitsizliklerin kaldırılması, yasa önünde eşitlik, vergilendirmede adalet, mülkiyet hakkı, seyahat ve düşünce özgürlüğü öngörülmüştür (Çam, 2000: 149). Diğer önemli bir gelişme ise 1948 y1lında Birleşmiş Milletler tarafından kabul edilen "İnsan Hakları Evrensel Bildirgesi"dir.

İnsan hakları adına atılan bu iki önemli adımla aynı zamanda insan hakları eğitiminin de yolu açılmıştır. 1789 Fransız Devrimi lideri Danton'un "Herkes bilmelidir ki çocuklar, ana babalarından önce Cumhuriyet'in yavrularıdır" sözü, devrim açısından eğitimin önemini vurgulamaktadır (Altunya, 2003: 4). İnsan Hakları Evrensel Bildirgesinin Başlangıç bölümünde yer alan "Eğitim, insan kişiliğini tam geliştirmeye ve insan haklarına ve temel özgürlüklere saygıyı güçlendirmeye yönelik olmalıdır. Eğitim tüm uluslar, ırklar ve dinsel gruplar arasında anlayış hoşgörü ve dostluğu özendirmeli ve Birleşmiş Milletler'in barışı koruma yolundaki etkinliklerini daha da geliştirmelidir" maddesiyle eğitimin önemi vurgulanmıştır (Kepenekçi, 2000). İnsan Hakları Evrensel Bildirgesi'nin eğitimin önemini vurgulayan bu maddesi aynı zamanda bildirgeyi imzalayan devletlere insan hakları eğitimiyle ilgili sorumluluklar da yüklemektedir.

İnsan haklan eğitiminin yalnızca insan haklarını öğretme olarak algılanmasının nitelikli bir insan hakları eğitimi ile bağdaşmayacağını söylemek pek de yanlış olmaz. İnsan hakları eğitimi aynı zamanda bu hakların bireyler tarafından içselleştirilmesini sağlamayı hedeflemektedir. Demokratik bir şekilde belirlenen sınırlar içinde, anlaşmazlık, adalet, özgürlük, eşitlik, insan onuru, karşllıklılık, dayanışma, görevler, yükümlülükler ve tabii ki her türlü haklar (insan, doğa, sivil, siyasi, hukuki, ekonomik, azınlık vs.) insan hakları eğitimiyle ilişkilendirilen en önemli kavramlardır (Lynch, 1989). Paylaşılan bir değer olan insan haklarını kapsayacak çalışmalar doğrultusunda eğitilen kişiler, saygın, barışçıl, 
eşitlikçi, demokratik ve şiddete karşı bir eğilim sergileyeceklerdir (Ravazzolo, 1996). Bu eğilimlerin sergilenmesi de ancak bireylerin insan haklarını içselleştirmesiyle mümkün olabilir.

Uluslararası hukukta insan hakları eğitiminin bir yükümlülük olarak yerini alması yalnızca İnsan Hakları Evrensel Beyannamesinin bir sonucu değildir. Avrupa Konseyi'ne üye ülkeler, insan haklarının tüm demokratik toplumlar için evrensel, bölünmez ve esas olduğuna inanır.

Konsey İnsan Haklarını, etkili denetim ve koruma mekanizmaları ile bireylerin sivil ve siyasal özgürlükleri, sosyal, ekonomik ve kültürel haklarına saygıyı ve güvence altına alarak;

- İnsan haklarına yönelik yeni tehditleri tanımlamak ve;

- Meslek grupları, okullar ve üniversitelerde insan hakları eğitimini geliştirmek ve kamuoyu bilincini oluşturmak suretiyle korumaya çalışır

Avrupa Konseyi'ne üye ülkeler, geçen 50 yıllık süre zarfında bu hakları, Avrupa İnsan Hakları Sözleşmesi, ve bu sözleşmenin tamamlayıcısı niteliğindeki Avrupa Sosyal Şartı, İşkence ve İnsanlık Dışı veya Aşağılayıcı Muamele ve Cezayı Önleme Avrupa Sözleşmesi ve Ulusal Azınlıkları Koruma Çerçeve Sözleşmesi olmak üzere dört temel belgede toplamışlardır (Avrupa Konseyi, 2006):

Bu belgelerden ilki olan Avrupa İnsan Hakları Sözleşmesi'nin Giriş Bölümü'nde üye devletler arasında sıkı birliği kurma amacına ulaşma yollarından birinin insan haklarını ve temel özgürlükleri korumak ve geliştirmek olduğu vurgulanmıştır (Kepenekçi, 2000). İnsan hakları eğitimi Sözleşme'nin imzalanmasıyla üstlenilen yükümlülüklerin kaçınılmaz bir sonucudur. Bu sorumluluk, Çocuk Haklarına Dair Sözleşme, UNESCO'nun 1974 'te kabul edilen Uluslar Arası Anlayış, İşbirliği ve Barış İçin Eğitim ve İnsan Haklarına ve Temel Özgürlüklere İlişkin Tavsiye Kararı, Avrupa Konseyinin 1978 tarihinde kabul edilen İnsan Hakları Öğretimi Kararı ve 1985 'te kabul edilen Okullarda İnsan Haklanı Öğretim ve Öğrenimi Tavsiye Kararı ile pekiştirilmiştir (Kepenekçi, 2000). Alınan kararlar ve 1993 yılında Montreal'de düzenlenen İnsan Hakları ve Demokrasi Eğitimi Uluslar Arası Kongresi gibi toplantılar Avrupa ülkelerinin uluslar arası düzeyde insan hakları eğitimine verdiği önemin bir göstergesidir. Gösterilen önemin bir sonucu olarak ortaya çıkan insan hakları eğitimiyle ilgili 
çabalara Türkiye'de kayıtsız kalmamış, 1990'lı yıllarla birlikte insan hakları eğitimiyle ilgili Türkiye'de de somut çalışmalar yürütülmeye başlanmıştır.

\section{Türkiye'de İnsan Hakları Eğitiminin Gelişimi}

Türkiye'de insan haklan eğitimi "Vatandaşlık Bilgileri ve İnsan Hakları Eğitimi” dersi adı altında 1990'lı yıllardan itibaren öğretim programlarına girmiştir. Vatandaşlık Eğitiminin tarihi ise II. Meşrutiyet dönemine kadar tahttan indirir. 1876 yılında ilan edilen Kanun-1 Esasi II. Abdülhamit'in Esasi'nin 1876 yılındaki Böylece Türk tarihinde illapısı hemen hemen temelinden yenilenmiştir. Küzeci, 2003). Anayasal rejim, anayasal rejim kurulmuştur (Mumcu ve uyuşmamış ve Cumhuriyet Osmanlı Devleti'ndeki "teba" anlayışıyla vazgeçilmez dersi "Yurttaşlı Bilginemi boyunca ilk ve ortaöğretimin ve İktisadiye" adıyla II. Mesrutiyet'," "Malûmat-1 Medenîye ve Ahlâkiye bir ders olarak okutulmaya baş in ilanı sonrasında okullarda bağımsız Cumhuriyet'e geçiş ayn için, Türkiye'de vatands zamanda tebaadan yurttaşa geçiş anlamını taşıdığı ortaya çıktığını söylemek yanlıs olmaz.

II. Meşrutiyet Dönemi'nde eğitim reformları içinde yer alan ve 1913 tarihinde geçici ilköğretim kanunu (Tedrisat-1 İptidaiye Kanun-1 Muvakkati) olarak kabul edilen kanunun bazı maddeleri Cumhuriyet Dönemi'nde 1950'li yıllara kadar yürürlükte kalmıştır (Binbaşığlu,1995). Bu kanun, ilköğretim sisteminin yenilenmesi ve halkın desteği yoluyla daha iyi bir öğretim programının gerçekleştirilmesi amacıyla çıkarılmıştır (Kaya, 1977). Kanunla birlikte iptidaiye ve rüştiye okulları birleştirilmiş ve Mekatib-i İbtidayiye-yi Umumi (İlköğretim Genel Okulu) adını almıştır. Böylece ilköğretim 6 yıl ve zorunlu olarak kabul edilmiştir (Akyüz, 1997; Başaran,

Geçici İlköğretim Kanunu ile birlikte, ilköğretim programlanna giren Malûmat-ı Medeniye ve Ahlâkiye ve İktisadiye (Vatandaşlık - Ahlâk İktisat) dersi, uyruğun devlete karşı görevleri, padişah ve devlet kurumlarına ve memurlarına itaat, Meşrutiyet yönetiminin iyilikleri, belediyelerin görevleri gibi konulan içermiştir. Bu ders, 1914 yılında kabul edilen Mekatib-i İbtidayiye-yi Umumiye Talimatnamesi (İlköğretim Okulu Programı) ile Mushabat-1 Ahlâkiye adinnı almıștır (Aky (Ilköğretim Okulu 1982; Altunya, 2003). Temeli I adinı almıştır (Akyüz, 1997; Cicioğlu, 
vatandaşlık eğitimiyle ilgili değişimler, Cumhuriyet'in ilanıyla birlikte hız kazanmıştır.

Dünyada, modern eğitimin geliştirilmesi ile ilgili önemli adımlar atılırken, son yüzyıllarda fikir ve bilim alanlarında meydana gelen gelişmeleri izleme yeteneğini kaybeden eğitim kurumları, II. Meşrutiyet'in sonuçsuz reformları hariç ihmal edilmiştir. $\mathrm{Bu}$ durum, Osmanlı Devleti'nden Türkiye Cumhuriyeti'ne miras kalan eğitimin gelişmiş älkelere göre nitelik ve nicelik yönünden oldukça geri kalmasının öncelikli nedenini oluşturur (Öztürk, 2005). Altı yüzyll tek bir hanedanın egemenliğinde varlığını sürdüren Osmanlı Devleti, zorlu bir bağımsızlık nücadelesi olan İstiklâl Savaşı'nın sonunda ulus egemenliğine dayalı bir levlet olan Türkiye Cumhuriyeti'ne dönüşmüştür (Oktay, 2004). Bu lönüşüm, pek çok alanda yapılan reformları zorunlu kılmıştır. Türkiye Cumhuriyeti kurulduğu günlerde, yeni bir devletin dayandığı temel ilkeleri alka benimsetme sorumluluğunu almıştır. Bir yandan Osmanl mirası ğitimin nitelik ve nicelik yönünden iyileştirilmesi zorunluluğu, diğer randan bireylerde Cumhuriyet'in dayandığı temel ilkeleri benimsetecek lavranış ve düşünüş değişikliklerini meydana getirme fikri, eğitim alanında rapılan reformların çıkış noktasıdır. 1923 yılında Millî Eğitim Bakanlığı arafından çıarılan bir genelgeyle okullarda Cumhuriyet'in ilanını da çerecek biçimde değiştirilen anayasanın öğretilmesi istenmiştir. /atandaşlık eğitimiyle ilgili bu ilk gelişme Cumhuriyet Dönemi'nin de ilk nemli program değişikliğidir (Altunya, 2003). Bu dönemde, öğretim rogramlarında yapılan ilk değişimin vatandaşlık eğitimiyle ilgili olması, 'umhuriyet'in ilk yıllarında, eğitimin öncelikli amacının vatandaş etiştirme olarak benimsendiğini göstermiştir.

Öğretimlerin birleştirilmesi anlamına gelen ve 3 Mart 1924 yılında abul edilen 7 maddeli Tevhid-i Tedrisat Kanunu'yla birlikte okullar rasındaki ikiliğe son verilmiş ve Millî Eğitim Bakanlığı'nın sorumluluğu Itında lâik bir eğitim sistemi kurulmuştur (Kaya, 1977; Binbaşığlu 1995; akaoğlu 1992). Kanunun kabulünden hemen sonra Cumhuriyet önemi'nin ilk öğretim programı uygulamaya konmuştur. Bu programla irlikte Osmanlı Devleti döneminde okutulmaşına karar verilen Müsahabat-1 Ahlâkiye dersi, Musahabat-1 Ahlâkiye ve Malûmat-1 ataniye" adını almıştır (Cicioğlu, 1982; Tazebay ve diğerleri; 2000 ltunya, 2003). Aynı ders 1926 tarihli İlkokul Programı'nda "Yurt Bilgisi", 948 yılında yapılan ilkokul programı reformuyla "Yurttaşlık Bilgisi" adını 
almıştır (Cicioğlu, 1982; Sakaoğlu 1992; Tazebay ve diğerleri, 2000; Altunya, 2003; Aybay, 2004; Üstel, 2004). 1968'de kabul edilen İlkokul Programı'nda tarih, coğrafya ve yurttaşlık bilgisi dersleri, tabiat bilgisi, aile bilgisi ve tarım-iş derslerinin "Fen ve Tabiat Bilgileri" adı altında birleştirildiği gibi "Sosyal Bilgiler" dersi adı altında birleştirilmiştir (Cicioğlu, 1982; Arslan, 2000; Tazebay ve diğerleri, 2000; Altunya, 2003). Aynı program 1975 yılında bazı değişikliklere uğramış ve Sosyal Bilgiler dersi temel eğitimin I. Kademesinde 4 ve 5 . sinıflarda haftada üç saat okutulmuştur. Ancak, Cumhuriyet Dönemi'nde vatandaş yetiştirme yalnızca "Vatandaşlık Bilgisi" dersinin bir sorumluluğu olmamış, aynı sorumluluğu sosyal bilimlerle ilintili, Tarih, Coğrafya ve Sosyal Bilgiler dersleri de üstlenmiştir (Sarıcan, 2006).

İnsan Hakları Derneği ve Türkiye İnsan Hakları Vakfı'nın 1990'da faaliyete geçmesi, aynı yıl 3686 sayılı yasayla "İnsan Hakları İnceleme Komisyonu"nun, 1994 yılında "İnsan Hakları Baş Müşavirliği”"nin ve bu komisyonla ilgili olarak "İnsan Hakları Yüksek Danışma Kurulu”nun kurulması insan hakları eğitiminin vatandaşlık eğitimi ile birlikte öğretim programlarına dâhil edilmesiyle ilgili gelişmeler arasındadır. 1994 yılı, aynı zamanda Birleşmiş Milletler Genel Kurulu'nun "eğitim, bilgilendirme ve bilgi yayma yoluyla bilgi ve beceriler kazandırmak, tutum ve davranışlar şekillendirerek evrensel insan hakları kültürünü oluşturmak" amacıyla 1995-2004 yıllarını "İnsan Hakları Eğitimi On Yıllı olarak ilan ettiği tarihtir (Üstel, 2004: 284-285). Böylece 1995 yll itibariyle "Vatandaşlık Bilgileri" dersi "Vatandaşlık Bilgileri ve Insan Hakları Eğitimi" adını almış, insan hakları eğitim öğretim programlarında yer almaya başlamıştır.

Yukarıda sözü geçen "İnsan Hakları Eğitimi On Yılı" çerçevesinde programa katılan diğer ülkeler de olduğu gibi Türkiye'de de çeşitli çalışmalar yapılmıştır. İnsan Hakları Eğitimi On Yılı Komitesi 2000 yılı çalışmalarında yapılanlardan bazıları şöyle sıralanabilir (İnsan Hakları Eğitimi On Y1lı Ulusal Komitesi, 2001):

- Ders Kitaplarının Gözden Geçirilmesi: Ulusal Program'da ilk ve ortaöğretimde insan hakları eğitimiyle ilişkili olarak okutulan, Millî Eğitim Bakanlığı'nca ders kitabı olarak hazırlanan kitaplar, kabul edilmeden önce, bu kitapların amaçlanan insan hakları eğitimini gerçekleştirebilirliklerinin değerlendirilmesi için Ulusal Komiteyle İşbirliği yapılması istenmiştir. 
Sokakta Çalışan ve Yaşayan Çocuklar Sorunu: Konuyu bütünüyle ele alan aşamalı olarak gerçekleştirilebilecek uzun vadeli bir projeyi hazırlamak üzere bir çalışma grubu oluşturulmuştur.

- Hâkim ve Savcıların Eğitimi: Bașta infaz ve koruma memurları olmak üzere bütün ceza evi personelinin hizmet öncesi eğitim konusunda çalışacak ve insan hakları eğitimine de yeteri kadar yer veren programlar hazırlayacak bir çalışma grubu oluşturulmuştur.

- Polislerin Eğitimi: Bu eğitimi gerçekleștirmek üzere Program’da yer alan anlayış çerçevesinde bir çalışma grubu oluşturulmuştur. Ulusal Komite Başkanlığı Emniyet Genel Müdürlüğü'nün çeşitli birimleri tarafından düzenlenen hizmet içi eğitim programları çerçevesinde yer alan insan hakları konusunun öğretimine katkıda bulunmuştur.

Ulusal Komite tarafından alınan kararların bazılarının tümü bazılarının ise bir kısmı kurumlarda yaşanan aksaklıklar ya da farklı nedenlerle ne yazık ki gerçekleştirilememiş ve yarım kalmıştır.

İnsan Hakları Eğitimi Niteliksel Tarama Grubu'nun raporunda, belirli ölçütlere, ilköğretimin 7. ve 8. Sınıf Vatandașlık ve İnsan Hakları Eğitimi kitaplarında, "doğrudan insan haklarına aykırı ifadeler, temel insan hakları kavramlarında yanlışlar, kasti saptırmalar, görmezden gelmeler" bulunmuştur. "Özellikle belli bașlı uluslar arası insan hakları belgelerinde belirtilen ilklere aykırı düşünce ve ifadelerin yer aldığına" işaret edilmiştir (Gök, 2003: 159).

\section{Farklı Ülkelerde İnsan Hakları Eğitimi}

İnsan hakları eğitimi uluslar arasında gerçekleştirilebilecek bir programı gerektirir. Dünyada insan haklarıyla ilgili bir bilinç oluşmuş ve insan hakları genellikle uluslar arası bir çerçeve içinde ele alınmıştır (Kepenekçi, 2000). İnsan hakları eğitimi yalnızca teorik bir takım bilgilerden oluşmamalı, genç bireylere okul yaşantısı içinde yeteneklerini uygulayabilme ve geliştirebilme olanağı sağlamalıdır. İnsani değerlerle bütünleştirilmiş nitelikli bir öğretim programı barış, sosyal birliktelik, insan değerine ve haklarına saygı gerçeği için gereklidir. Böyle öznelerle dolu : eğitimi gerçekleştirebilmek için geleneksel eğitim modelleri demokratik eğitim modelleriyle yer değiştirmelidir (UNESCO, 2006). Bu amaçtan hareketle Avrupa ülkelerinde demokrasiye uyum sağlayabilecek vatandaşlar yetiştirmek ve nitelikli insan hakları eğitimin gerçekleştirmek için pek çok uygulama yapılmaktadır. 


\section{1. İngiltere İnsan Hakları Eğitimi}

İngiltere eğitim sisteminin amacı eğitimden faydalanacaklar için kapsamlı bir hizmet hazırlamaktadır. Eğitim, çocuklar için mutlu bir çocukluğu ve hayata daha iyi bir başlangııı teminat altına almak, gençler için firsat eşitliğini sağlamak, herkes için alanlarında çeşitli hünerlerini geliştirerek ülkelerine zengin bir miras bırakılacak gelir teminini hazırlamak için kullanılan bir araç olarak görülmektedir (Demirel, 1996).

İngiliz siyasi rejimi bütün ayrıtılarıyla teorinin eseri olmaktan çok deneysel görüntüye sahiptir ve tarihi bir gelişim sonucu yavaş yavaş oluşmuştur (Çam, 2000). Bu siyasi rejimin değişikliğinden İngiltere'deki diğer sistemler gibi İngiliz eğitim sistemi de çeşitli etkiler altında kalmıştır. İngiliz Eğitim Sistemi Orta Çağda Romalıların, 16. yüzyılda Rönesans ve reformcuların, 19. yüzyılda da J.J. Rousseau, Pestallozzi ve John Dewey gibi eğitimcilerin etkisi altında kalmıştır (Demirel, 1996). Çağdaș İngiliz Eğitim Kurumlarının kökeni ise on beşinci ve on altıncı yüzyıla kadar uzanan ve on sekizinci yüzyılda kurumlaşmaya başlayan "Gramer Okulları"na dayanmaktadır. Bu okullar arasında en önemli ve başarılı olanlar "Halk Okulları (Public School)" adıyla ün kazanmışlardır (Erdoğan, 1998). Kurumlardaki eğitim anlayışı zamanla değişmiş ve bugünkü halini almıştır.

İngiltere'de insan hakları eğitiminin ortaya çıkışının devletin eğitime müdahalesi ile gerçekleştiğini söylemek yanlış olmaz. Eğitimin önemi ülke genelinde tanınmaya başladıkça devletin eğitime müdahalesi de gerçekleşmiştir. Devletin eğitimle ilgilenmesine neden olan başka bir etken de uluslar arası düzeyde kabul gören yeni anlayışlardır. Birleşmiş Milletlerin İnsan Hakları Bildirgesiyle her insanın eğitilmesini özgürlük gibi temel bir hak olarak kabul etmesiyle İngiltere'de eğitim diğer hizmetler gibi bir insan hakkı olarak görülmeye başlanmıştır (Evetts, 1973, akt: Erdoğan, 1998). İnsan Hakları'nın öneminin anlaşılması insan hakları eğitimini de zorunlu kılmıștır.

Uluslararası hukukta insan hakları'nın tarihsel gelişimi dikkate alındığında, bugün İngiltere'nin de insan hakları eğitimi sorumluluğunu üstlenen devletlerden biri olduğu görülmektedir. İngiltere'de vatandaşlik ve insan hakları eğitimi yalnızca yerel ya da ulusal değil ulusalar arası bir değer olarak görülmektedir (Douglas, 2003). 2002 yllında İngiltere'de vatandaşlık okullarda yasalarla belirlenmiş yeni bir özne olarak ortaya 
çıkmıştır (Council of Europe, 2006). Bununla birlikte "The Departmant For Education and Skills" tarafindan 2003 Kasım ayından başlayarak, her y1l Kasım ayının ilk haftası Uluslararası Eğitim Günü olarak belirlenımiștir. Uluslararası iletişim yoluyla insan hakları eğitimiyle ilgili yapılan uygulamalardan birinde İngiltere'deki bir okul Hindistan'daki bir okulla video konferansı ve dijital kameralarla bağlantı kurarak birlikte çalışma firsatı bulmuştur (Douglas, 2003). Bu uygulama öğrencilerde kültürlerarası etkileşimin kazandırılması yönünde kullanılabilecek bir örnektir.

İngiliz okul sisteminde insan hakları eğitimi teorik bilgi aktarımında çok sosyal etkinliklerle yapılmaktadır. Bir taraftan bilim, tarih, coğrafya ve felsefe konularından diğer taraftan da sportif, müzik ve dinsel faaliyetlerden faydalanılarak öğrencilerin disiplin, özgürlük, kendisine saygı ve güven gibi kişilik özellikleri geliştirilmeye çalışılır (Bilhan, 1996: akt, Yeşil, 2002). Büyük sınıflarda ise insan hakları öğretimi daha esnek bir șekilde gerçekleştirilir. İnsan hakları eğitimi, tarih ve vatandaşlık dersleriyle sınırlı değildir. Öncelikle insan hakları sorunu belirlenir ve tartışmalar yoluyla çözümler üretilir (Büyükkaragöz, 1989, akt: Yeşil, 2002).

İngiltere'de insan hakları eğitimini gerçekleştiren örgün eğitim kurumları dışında sivil toplum kuruluşları da konuyla ilgili faaliyetlerde bulunmaktadır. Justice (Adalet) isimli sivil toplum kuruluşu buna örnek olarak gösterilebilir. Bugün, politikaların geliştirilmesinde ve politika üretilmesinde ön plana çıkan kuruluş, mecliste bir yasa çıkacağında bunların İnsan Haklarına uygun olup olmadığı kontrol ederek, görüş bildirerek ve kulis yaparak bir çeşit baskı unsuru haline gelmiştir. İngiltere'de İnsan Hakları Yasasının çıkması sürecinde de sürekli görüş bildirerek katkı sağlamıştır. İnsan Hakları alanında eğitim faaliyetlerinde de bulunan "Justice" özellikle hukuk alanında konferanslar düzenlemektedir. Ayrıca kamu kuruluşlarına eğitim vererek faaliyetlerde bulunmaktadır. Özetle Justice'ın İnsan hakları politikaları geliştirme ceza adaleti, hukuk devleti, AB hukuku gibi alanlarda çalıştığı söylenebilir (Boğaziçi Üniversitesi Avrupa Çalışmaları Merkezi, 2006).

İngiltere'de insan hakları eğitimiyle ilgili çalışmalarda bulunan resmi ve sivil kuruluşların aktiviteleri dışında, insan hakları eğitimiyle ilgili veri toplamaya yönelik bilimsel çalışmalar da yapılmaktadır (Kepenekçi, 2000). İnsan hakları eğitimiyle ilgili yapılan bilimsel çalışmalar, uygulama alanında insan hakları eğitiminin geliştirilebilmesi için çalıșıldığının bir göstergesidir. 


\subsection{Fransa'da İnsan Hakları Eğitimi}

1789 Fransız Devrimi ile birlikte Fransa'da mutlak monarşinin hâkim olduğu rejime son verilmiştir. Devrim modern siyasi fikirlerin kurumlara yerleşmesine yol açmıştır (Çam, 2000). Fransız Devrimi'nin getirdiği temel ilkeler "insan hakları" başlığı altında toplanabilir.

İnsan hakları, Devrim'in bir mirası olarak millî özellikler içersinde gitgide yer etmeye başlamıştır. Bu temel ilkeler "hürriyet, eşitlik ve kardeşlik" olarak sıralandırılabilir. Bu ilklerin gerçekleştirilmesi için eğitim Fransa'da bir ön şartı teşkil etmiştir (Aytaç, 1998). Bu nedenle Fransa'da insan hakları eğitiminin temellerinin Fransız Devrimi'ne dayandığını söylemek yanlış olmaz.

Fransız düşünür Condorcet'in Fransız Devrimi sonrasında Milli Eğitim Üzerine hazırladığı rapor günümüzde de etkisini korumaktadır. Bu raporda sunulan görüşlere göre okullar, insanları eğitim ve öğretim yoluyla kendi haklarını gerektiği gibi kullanabilecek, ihtiyaçlarını karşılayabilecek ve onları toplumsal ve mesleki hayata hazırlayacak iyi bir araç olmalıdır (Çam, 2000). Bu tanım bu gün insan hakları eğitiminin amaçlarıyla da örtüşmektedir. Düşünürün Fransız eğitimine olan etkileri düşünüldüğünde, insan hakları eğitiminin Fransa'da diğer Avrupa ülkelerinden daha erken bir dönemde başladığı düşünülebilir.

Eğitimin kurumsal anlamda lâikleşmesinin ilk olarak gerçekleştiği Fransa'da İlköğretim programları iki ana değeri merkeze alarak şekillendirilmiştir. Bunlardan biri, öğrencilerde evrensel insan hakları anlayışıııı oluşturulması amacıyla öz saygı ve kişisel sorumluluk geliştirmek, diğeri ise öğrencinin okul ve okul dışındaki etkinliklere katılımını sağlamaktır (Council of Europe, 2006). Bu iki değer, Fransa'da henüz ilköğretim yıllarında insan haklarına verilen önemin bir göstergesi olabilir. Ortaöğretimde ise, ortaöğretimin birinci yılından itibaren öğrenciler insan hakları ve sorumluluklarını ve öğrenci hak ve sorumluluklarını öğrenirler (Council of Europe, 2006). UNESCO, Fransa'da örgün eğitimin içinde yapılan insan hakları eğitimiyle ilgili bazı uygulamaları şöyle aktarmıştır (akt.Yeşil, 2000: 66-68):

Fransa'da yapılan çalışmaların en çarpıcı yönü özel bir "İnsan Hakları Günü’nü düzenlemiş olmasıdır' Öğrenciler bu özel günde değişik konuşmacılar dinler ve görüşlerini bildirirler. 
- Nice'de yer alan bir okulda öğrenciler iki gruba ayrılmışlardır. Birinci grup bireysel özgürlük ikinci grup ise açlık sorununu ele alarak 3 . Dünya ülkeleri üzerinde odaklanmışlardır.

- “İnsan Haklarının Okullarda Uygulanması Programı"nda, öğretmenler hem eğitsel hem de ahlâki değerleri öğrencilere vermeye çalışmışlardır. Etkinlikler sırasında, öğrencilerin konuşma, kompozisyon yaratıcı ve hayal ürünü çalışmalar ortaya koyma ve eleştirel ve tarafsız karar verme yeteneklerinin geliştirilmesini sağlayan araştırmalara yer verilmiştir.

Yapılan etkinliklerden de anlaşıldı̆̆ı gibi Fransa'daki okullarda hem demokrasilere uyum sağlayabilecek aktif vatandaş yetiştirmeyi, hem de insan hakları eğitimini ön plana çıkarmayı amaçlayan etkinlikler uygulanmaktadir.

\subsection{Diğer Avrupa Ülkelerinde Yapılan Uygulamalar}

Devlet gücünün Federal Devletlere bölüştürüldüğü Almanya'da eğitim sistemi de eyaletlere göre farklılık göstermektedir ve merkezi bir eğitim bakanlığı yoktur (Demirel, 1996). Ülkede eğitim hakkı ve eğitim özgürlüğü temel bir hak olarak kabul gördügü ve insan hakları eğitiminin tarih ve vatandaşlık dersleriyle bütünleştirildiği Almanya'da insan haklanı eğitimiyle ilgili olarak;

- insan hakları konusunda bilgilendirilmiş öğretmenlere

- insan haklarını etkili ve nitelikli bir biçimde sunmanın yollarını arayan araștırmalara

- her yaş grubuna uygun öğretim materyallerine önem ve öncelik verilmektedir (Yeşil, 2002).

Polonya, Romanya ve Slovakya gibi orta ve doğu Avrupa ülkelerinin çoğunda insan haklarına iliş̧kin bilgiler; ahlàk bilgisi din bilgisi, dil vatandaşlık bilgisi ve tarih gibi çeşitli derslere ya da konu alanlarına yerleştirilıniştir. Böyle dersler, program doğrultusunda birbirileriyle ilişkili olarak işlenir ya da ögretmenler aracılığıyla yapılan haftalık açık saatlerde konu edilebilir (Tibbits, 1994, akt: Yeşil, 2002).

Politik sistemindeki değişiklik sonrası Avrupa Birliği ile bütünleşme sürecine giren Polonya, Birlik ilkelerine uyum zorunluluğu ve 6-7 yaş nüfusta ciddi bir demografik düşme faktörlerine bağlı olarak, büyük bir 
eğitim reformu yaşamaktadır. Planlanan eğitim reformu aşağıdaki amaçlara dayanmaktadır:

- Akademik disiplinlere göre tasarlanmıs, ayrıntılı ve aşırı yüklü ansiklopedik ögretim yaklaşımını terketmek,

- Öğrencileri, yeterlilik ve etkinliğe ulaştırmanın yanında, kendi-kendini eğitmeye devam edebilmeleri ve yaşamdaki sorularla başa çıkabilmeleri için, kendi gücüne dayanamaya ve bağımsız olmaya hazırlamak,

- Öğrencilerin zihinsel ve harekete dayalı uyaranlarını ve geçmiş yaşantılarını dikkate alarak, tercihlerini açığa çıkararak, onun için en uygun eğitimsel yolları saptayıp, özgün gelişimine önem vermek, kendini gerçekleştirmesini desteklemek; böylece kendine ve başkalarına karşı sorumluluk, özgüven, yararlı olma duygusu, ekip çalışması, yurtsever ve özgecil sosyal tutumlar, iletişim ve kendini ifade etme becerisi geliştirmesini kolaylaştırmak.

- Okulların özerkliğini arttırmak ve öğretmenlerin yöntem ve teknik seçmede özgürlüğünü tanımak; yalnızca genel amaçlarda merkezi programa uyma zorunluluğu,

- Ayrıntılı ve gerekçeli biçimde hazırlanmış ve okul eğitim kurulu onayından geçmiş, okulun özel amacına uygun özgün programların yararını kabul etmek, merkeziyetçilikten uzaklaşmak. (Ulusavaş, 2000).

Yukarıdaki maddelerde, eğitimde yapılan değişiklik sonrasında insan hakları uygulamaları açısından uygun ortamın oluşabileceği görülmektedir. Uluslararası Eğitim Anlayışı İçin Eğitimde Ortak Okullar Projesi kapsamında çeşitli ülkelerden okullarda olduğu gibi Polonya'da da bir uygulama yürütülmüştür. Bu uygulamada, öğretmenler farklı ülkelerden ögrencilerle mektuplaşmış, ögrencilerle ortak çalışılarak Polonya'yı tanıtıcı bir albüm hazırlanmıştır. Mektuplaşılan diğer ülkeler de kendi ülkeleriyle ilgili tanıtıcı bir albüm hazırlayarak bu projeye dâhil olmuşlardır. Hazırlanan albümler farklı ülkelerle değiştirilerek, öğrencilerin çeşitli kültürleri tanıması ve buna bağlı olarak hoşgörü geliştirmesi hedeflenmiştir (Kepenekçi, 2000).

Temel eğitimin, 7-17 yaşlar arası parasız ve tüm yurttaşlar için zorunlu olduğu Finlandiya'da eğitim sisteminin vazgeçilmez ilkeleri şöyledir (Elo, 1998, akt: Ulusavaş, 2000):

- Herkes için eşit eğitim firsat ve olanakları

- Öğrencilerin istek ve görüşlerine saygı 
- İfade özgürlüğ̈̈

- Yeterli bilgiye ulaşma hakkı

- Düşünce, vicdan ve inanç özgürlüğü

- Bağımsız öğrenmeye destek

$\mathrm{Bu}$ ilkelerden hareketle Finlandiya'da, global yurttaş yetiştirmek için bireyin kişisel gelişimini destekleyici bir uygulama başlatılmıştır. Amaç, tüm yaşam boyu öğrenme sürecine genel ya da mesleki-teknik alanlarda kolaylıkla uygulanabilen, bireyin kendince yönlendirebildiği bir açık öğrenme sürecini gerçekleştirmektir. Uygulamada katılımcıların insan hakları, kültür, çevre, kalkınma gibi konularda eleştirel tartışmaları artırdığını; yeni bilgilere ulaşma, bu bilgileri kullanma ve paylaşma için harekete geçtiği; etkileşim becerilerini arttırdığını ve kişiliklerini geliştirdiği saptanmıştır. Bu çok yönlü program aşağıdaki farklı alanları kapsamaktadır:

- Barış eğitimi

- Güvenli eğitimi (silahsızlanma)

- İnsan hakları eğitimi

- Çevre eğitimi

- Farklı kültürleri anlama eğitimi

- Hoşgörü eğitimi

- Kalkınma eğitimi

- Bilgi iletişim teknolojisi eğitimi (Ulusavaş, 2000).

Avrupa ülkelerinde çeşitli programlar kapsamında ya da örgün eğitimde gerçekleştirilen insan hakları eğitimi çalışmaları çeşitli bilimsel çalışmalar sonucunda daha nitelikli duruma getirilmeye ve geliştirilmeye çalışılmaktadır. Bu çaba gün geçtikçe insan haklarının öneminin aratmasıyla doğru orantılı olarak hız kazanmaktadır.

\section{Sonuç: İnsan Hakları Eğitimi'nin Neresindeyiz?}

Ülkemizde, insan hakları eğitimi ilköğretim programlarında 7 . ve 8 . sinıflarda "Vatandaşlık ve İnsan Hakları" dersi adı altında yer almaktadır. Bu dersin dışında ilköğretimin 1, 2 ve 3. kademesinde yer alan Hayat Bilgisi Dersi içinde, programın "kişisel nitelikler" başlığı altında, öğrencide oluşturulması hedeflenen bir takım dèğerler yer almaktadır. 4 ve 5 . sınıf Sosyal Bilgiler Öğretim Programı'nda ise değerler başlı̆̆ı altında öğrencide oluşturulacak değerler belirlenmiştir. Her iki dersin öğretim programında yer alan bu değerler incelendiğinde, değerlerin aktif vatandaş yetiştirme, demokrasi eğitimi ve insan haklanı eğitimiyle olan ilişkisi görülmektedir. 
$\mathrm{Bu}$ değerlerin gerçekleştirilmesine yönelik sınıf içinde yapılan etkinlikler insan hakları eğitimiyle ilişkilidir. İnsan hakları eğitimiyle ilgili yapılacak sınıf içi ve okul etkinliklerinin arttırılması, öğretmen ve anababaların insan haklarına uygun tutum ve davranış sergilemeleri, insan hakları eğitiminin öğrencilerde içselleştirilmesini kolaylaştıracaktır. Konuyla ilgili olarak halen görevde olan öğretmenlerin hizmet içi programlarla eğitilmesi, öğretmen adaylarının da üniversitelerde aldıkları sırasında bu konuda yeterli duyarlılı̆̆ı edinmiş olmaları gereklidir. Okulların ve öğretmenlerin demokratik tutuma sahip olmaları, insan haklarına saygı göstermeleri ve bu düşüncelerle örtüşen davranışlar sergilemeleri, bir başka ifadeyle, okulda demokratik ve insana saygılı bir iklimin yaratılması, bu niteliklerin ögrenciler tarafından da içselleştirilmesini sağlar.

Ayrıca çeşitli kurumların ve ailelerin insan haklarıyla ilgili olarak eğitim almalan amacıyla sivil toplum örgütlerinin de bilinçlendirilmesi ve çeşitli projeler kapsamında bu ve benzeri eğitimlerin verilmesi insan haklarının Türkiye'de işlevsel duruma gelmesi için gereklidir.

İnsan Hakları Evrensel Bildirgesinin bir başka boyutu da Çocuk Hakları Evrensel Bildirgesidir. Çocuk Hakları da, yetişkin haklarıyla çelişki içinde değildir; tersine insan hakları hukukunun bir parçasıdır. Çocukların diğer insanlara karşı özel haklara sahip olması değil, gelişme gereksinimleri nedeniyle özel insan haklarına sahip olması anlamına gelir (Akyüz, 2000: 3). İnsan Hakları Evrensel Bildirgesi ile Çocuk Hakları Sözleşmesinde yer alan maddeler birbiri ile örtüştüğünden, İnsan hakları eğitimine, öğrenmelerin en hızlı olduğu okul öncesi dönemde çocuk hakları eğitimi ile başlanması insan hakları eğitiminin hedeflerine ulaşabilmesi ve çağdaş demokratik toplumların oluşabilmesi açısından son derece önemlidir.

Yaşar'ın (2004) ifade ettiği gibi, çocuklar ilk kez okul öncesi eğitim kurumlarında planlı ve programlı olarak toplumsallaşma sürecini yaşarlar. $\mathrm{Bu}$ süreçte çocuklar, topluma uyum için gerekli olan bilgi ve becerilerin yanı sıra demokratik tutum ve davranışlar kazanmaya çalışırlar. Demokratik tutum ve davranışları benimseyen bireyler yetiştirmek suretiyle okul öncesi eğitim kurumları, geleceğin güçlü demokratik toplumlarının oluşmasına katkıda bulunurlar. Bir başka ifadeyle, çocuklar okul öncesi eğitim kurumlarında içinde yaşadıkları, toplumun ve ülkenin vatandaşı olma yönünde eğitilirler. Okul öncesi eğitim kurumları, çocukların ilk kez vatandaşlık bilinci kazanmaya başladıkları yerlerdir. Bu nedenle, bu 
kurumlarda gerçekleştirilecek demokratik eğitim uygulamalan, çocukları vatandaşlık bilincini kazandırma bakımından son derece önemlidir (Yaşar, 2004: 30). Şu anda uygulanan okul öncesi eğitim programında çocuk hakları eğitimini, uzun vadede ise insan haklan eğitimini (empati, başkalarının ihtiyaçlarına, duyarlı olma, barış, hoşgörü, farklılıklara saygı vb.) destekleyecek amaçlar ve kazanımlar mevcuttur. Okul öncesi dönemde, çeşitli yöntem ve teknikler (okul öncesi dönem çocuklarının gelişim özellikleri dikkate alınarak) kullanılarak çocuk hakları eğitimi bu döneme uygun olabilecek şekilde bütün bir eğitim yılı süresince planlanmış etkinliklerle uygulanmalıdır.

Erken dönemde verilecek bu eğitim, insan haklarının benimsenmesinde temel olarak görülmektedir. Bu dönemdeki öğrenmelerin ancak yaparakyaşayarak olduğu göz önüne alınırsa, çocukların bu dönemdeki kazanımlarının ilköğretimde de uygun koşullarla desteklenmesi önemlidir. Bu durum, haklara sayg1lı ve demokrasinin "hak ve sorumluluklar dengesi" olduğunu bilen ve bunu yaşama geçirebilen bireylerin yetişmesine yardımcı olacaktır.

Ülkemizde yürütülen insan hakları eğitimi uygulamalarının çeşitli Avrupa ülkelerinde yapılan çalışmalarla örtüştüğü ancak yeterli olmadığı söylenebilir. Bu nedenle insan haklannın bireyler tarafindan benimsenmesi hedeflense de, diğer ülkelerle yürütülen ortak çalışmaların sınırlı oluşu, ortak bakış açısının da gelişmesini engellemektedir. Geçmişe oranla önemli adımlar atılmış olmakla birlikte bu adımların geliştirilebilir olduğu görülmektedir. Ortak çalışmaların sınırlılı̆ğ yalnızca ülkemizle ilgili bir sorun değil, pek çok ülkenin de insan hakları eğitimiyle ilgili olarak yaşadı̆̆ 1 bir sorun olarak gözükmektedir. 


\section{Kaynakça:}

Akyüz. E. (2000). Ulusal ve Uluslar A ras! Hukukta Çocuğun Haklarınm ve Güvenliğinin Korunması. Ankara: Milli Eğitim Bakanlığı Yayınlan.

Akyüz, Y. (1997). Türk Eğitim Tarini. İstanbui: Kültür Koleji Yayınlan. Altunya, N. (2003). Vatandaslik Bi/gisi. Ankara: Nobel Yaym Dağıtum.

Avrupa Konseyi (2006). Erişim:2006, http. www avrupakonseyi.org.tr.

Aybay, R. (2004). Varandashk Hukuku, Itanbul: Istanbul Bilgi Universitesi Yaymian.

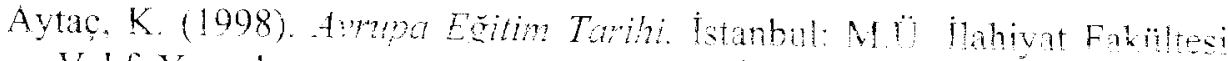
Vakfi Yaynlart.

Başaran, İ.E., (1996). Tükiye Eğhim Sisiemi. Ankara: Yargicı Matbaası.

Binbașioğlu, C. (1995). Türkiye'de Eğitim Bilmleri Tarihi. İstanbul: Millî Eğitim Bakanlığı Yayınları.

Boğaziçi Üniversitesi Avrupa Çalıșmaları Merkezı (2006). Adalete Erişim İcin Sürekli Mesleki Gelişim Projesi Sonuç Raporu. Erișim: 2006, http://www.ces.boun.edu.tr.

Cicioğlu, H. (1982). Türkiye Cumhuriyetinde Ilk ve Ortaöğretim. Ankara: Ankara Üniversitesi Basım Evi.

Council of Europe. (2006). Erișim: 2006, http.//www.coe.int.

Çam, E. (2002). Çağdaş Devlet Sistemleri. İstanbul: Der Yaymları.

Çeçen, A. (2000). Insan Hakları. Ankara: Savaş Yayınları.

Demirel, Ö. (1996). Karşılaştımalı Eğitim. Ankara: Usem Yayınları.

Doğan, İ. (2002). Modern Toplumda Vatandaşlk Demokrasi ve Insan Hakları İnsan Haklarının Kültüre Temelleri. Ankara: Pegem Yayıları, 3.Baskı.

Douglas, L. (2003). Citizenship education and human rights education: an overview of recent developments in the UK. England: British Council

Erdoğan, I. (1998).Çăgdaş Eğitim Sistemleri. İstanbul: Sistem Yaymlan 
Gök, F. (2003). "Vatandaşlık ve İnsan Hakları Eğitimi Ders Kitapları" Ders Kitaplarında İnsan Hakları: Tarama Sonuçları. (Ed. B. Cotuksöken, A. Erzan, O. Silier). İstanbul: Türkiye Ekonomik ve Toplumsal Tarih Vakfi İnsan Hakları Eğitimi On yılı Ulusal Komitesi. (2001). Insan Haklarl Eğitimi On yll.

Karakütük, K. (2001). Demokratik Lâik Eğitim. Ankara: Anı Yayıncılık.

Kaya, Y. K. (1977). Insan Yetiştirme Düzenimiz. Ankara: Nüve Matbaası.

Kepenekçi, Y. (2000). Insan Hakları Eğitimi. Ankara: Anı Yayınevi.

Lynch, J.(1989). Multicultural Education in a Global Society. Bristol, PA: Falmer Prest.

Mumcu, A. ve Küzeci, E. (2003). Insan Hakları ve Kamu Özgürlükleri. Ankara: Savaş Yayınları.

Oktay, A. (2004). "21 Yüzyılda Yeni Eğilimler ve Eğitim”. O. Oğuz, A. Oktay ve H. Ayhan (ed.). 21. Yüzllda Eğitim ve Türk Eğitim Sistemi. İstanbul: Dem Yayınları.

Öztürk, C. (2005). "Çağdaş Eğitim ve Bilim”. C. Öztürk (ed.). Imparatorluktan Ulus Devlete Türk Inkılâp Tarih. Ankara: Pegema Yayincilik.

Ravazzolo, T. (1996). "Human Rights and Citizenship". A. Osler, F. Rathenow ve H. Starkey (ed). Teaching for Citizenship in Europe. London: Trentham Books.

Sakaoğlu, N. (1992). Cumhuriyet Dönemi Eğitim Tarihi. İstanbul: İletişim Yayınları.

Sarıcan, E. (2006). “1998 ve 2005 Sosyal Bilgiler Öğretim Programlarının Vatandaşlık Değerleri Açısından Karşılaştırılması". Yayınlanmamış Yüksek Lisans Tezi. İstanbul: Marmara Üniversitesi Eğitim Bilimleri Enstitüsü.

Tazebay, A. Çelenk, S. Tertemiz, N. Kalaycı, N. (2000). İlköğretim Programlart ve Gelişmeler. Ankara: Nobel Yayın Dağıtım.

TİHAK. (1998). Tüm İnsanlar... İnsan Hakları Eğitimi İçin El Kitabı, Çev: Gümez, Mesut.UNESCO Yayınları. 
Ulusavaş, M. (2000). "Temel Yurttaşlık Eğitimi-Global Boyutlu Bir Çalışma" Pamukkale Üniversitesi IV. Ulusal Sinıf Ögretmenliği Sempozyumu.15-15 Ekim 1998.

UNESCO. (2006). Erişim: 2006. http://portal.unesco.org/education.

Üstel, F. (2004). Makbul Vatandaşın Peşinde. İstanbul: İletişim Yayınları.

Yargıya Erişim Projesi(2006). Erişim: 2006. http://www.inhakbb.adalet.gov.tr.

Yaşar, S.. (2004). "Çocuklara Vatandaşlık Bilincini Kazandırmada Okul Öncesi Eğitimin Rolü”, Marmara Üniversitesi Atatürk Eğitim Fakültesi I.Uluslar Arası Okul Öncesi Eğitim Kongresi Bildiri Özetleri. İstanbul: Ya-Pa Yayınları. Dağıtım. 